\title{
Bottled Biogas-An Opportunity for Clean Cooking in Ghana and Uganda
}

\author{
Mairi J. Black ${ }^{1}$, Amitava Roy ${ }^{2}$, Edson Twinomunuji ${ }^{3}{ }^{\circledR}$, Francis Kemausuor ${ }^{4}$, Richard Oduro ${ }^{1}$, \\ Matthew Leach ${ }^{1, *}$, Jhuma Sadhukhan ${ }^{1}$ and Richard Murphy ${ }^{1}$ (D) \\ 1 Centre for Environment and Sustainability, University of Surrey, Guildford GU2 7XH, UK; \\ m.black@surrey.ac.uk (M.J.B.); r.a.oduro@leeds.ac.uk (R.O.); j.sadhukhan@surrey.ac.uk (J.S.); \\ rj.murphy@surrey.ac.uk (R.M.) \\ 2 Engas UK Ltd., Horsham RH13 5JZ, UK; aroy@en-gas.co.uk \\ 3 Uganda Cleaner Production Centre, P.O. Box 69 Kyambogo, Kampala, Uganda; googomujuni@gmail.com \\ 4 The Brew-Hammond Energy Centre, Kwame Nkrumah University of Science and Technology, \\ Kumasi AK-039-5028, Ghana; fkemausuor.soe@knust.edu.gh \\ * Correspondence: m.leach@surrey.ac.uk
}

Citation: Black, M.J.; Roy, A.; Twinomunuji, E.; Kemausuor, F.; Oduro, R.; Leach, M.; Sadhukhan, J.; Murphy, R. Bottled Biogas-An Opportunity for Clean Cooking in Ghana and Uganda. Energies 2021, 14, 3856. https://doi.org/10.3390/ en14133856

Academic Editor: Attilio Converti

Received: 24 May 2021

Accepted: 22 June 2021

Published: 26 June 2021

Publisher's Note: MDPI stays neutral with regard to jurisdictional claims in published maps and institutional affiliations.

Copyright: (C) 2021 by the authors Licensee MDPI, Basel, Switzerland. This article is an open access article distributed under the terms and conditions of the Creative Commons Attribution (CC BY) license (https:/ / creativecommons.org/licenses/by/ $4.0 /)$.

\begin{abstract}
Anaerobic digestion (AD) can bring benefits in terms of effective management of organic waste, recovery of nutrients and energy recovery, and is consistent with circular economy principles. $\mathrm{AD}$ has been promoted and implemented worldwide, but at widely differing scales, influenced by the availability and location of feedstocks. In developing countries, feedstock arises from small- to medium-scale agriculture and agro-processing operations, as well as from household and municipal waste. Biogas produced from residues from agro-processing facilities may be used for on-site heat and power, but the lack of a gas and electricity grid infrastructure can limit opportunities to distribute gas or generated electricity to wider users. This paper presents the findings of the first study to consider novel technologies for small-scale and low-cost biogas clean-up into biomethane, and compression into small bottles, suitable as a clean cooking fuel. The paper reports on the initial evaluation of biomethane for cooking in Ghana and Uganda.
\end{abstract}

Keywords: clean cooking; anaerobic digestion (AD); biogas; biomethane; compressed natural gas (CNG); compressed biogas (bioCNG); waste management; energy access

\section{Introduction}

Biogas is a mixture of gases, primarily methane, arising from the fermentation of organic matter. Biogas is discussed here as the product of Anaerobic Digestion (AD) of a range of organic materials, e.g., from agro-residues and wastes, food and human waste, mixed municipal wastes, as well as from dedicated crops grown for energy production. AD technology and the resulting biogas produced have been playing an increasingly important role globally in the management of waste and in the provision of renewable, clean energy options for various applications.

The scale of production of biogas can be entirely flexible, depending on feedstock availability, levels of investment available and supporting policy mechanisms. Raw biogas can be used directly for heating, cooking and lighting, or it can be upgraded to biomethane, a term used to define methane $\left(\mathrm{CH}_{4}\right)$ produced from biogas, rather than methane from fossil natural gas. Biomethane is derived from biogas after the scrubbing/purification of the gases obtained from anaerobic digestion. It can be used to replace natural gas in gas grid systems, in the generation of power and heat when coupled with an appropriate conversion technologies (e.g., combined heat and power (CHP)) and as a gaseous vehicle fuel [1]. Figure 1 illustrates this range of uses with the position of upgraded biomethane for cooking highlighted. Biomethane can also be used as feedstock to produce chemicals and materials, replacing the methane derived from natural gas [2]. 


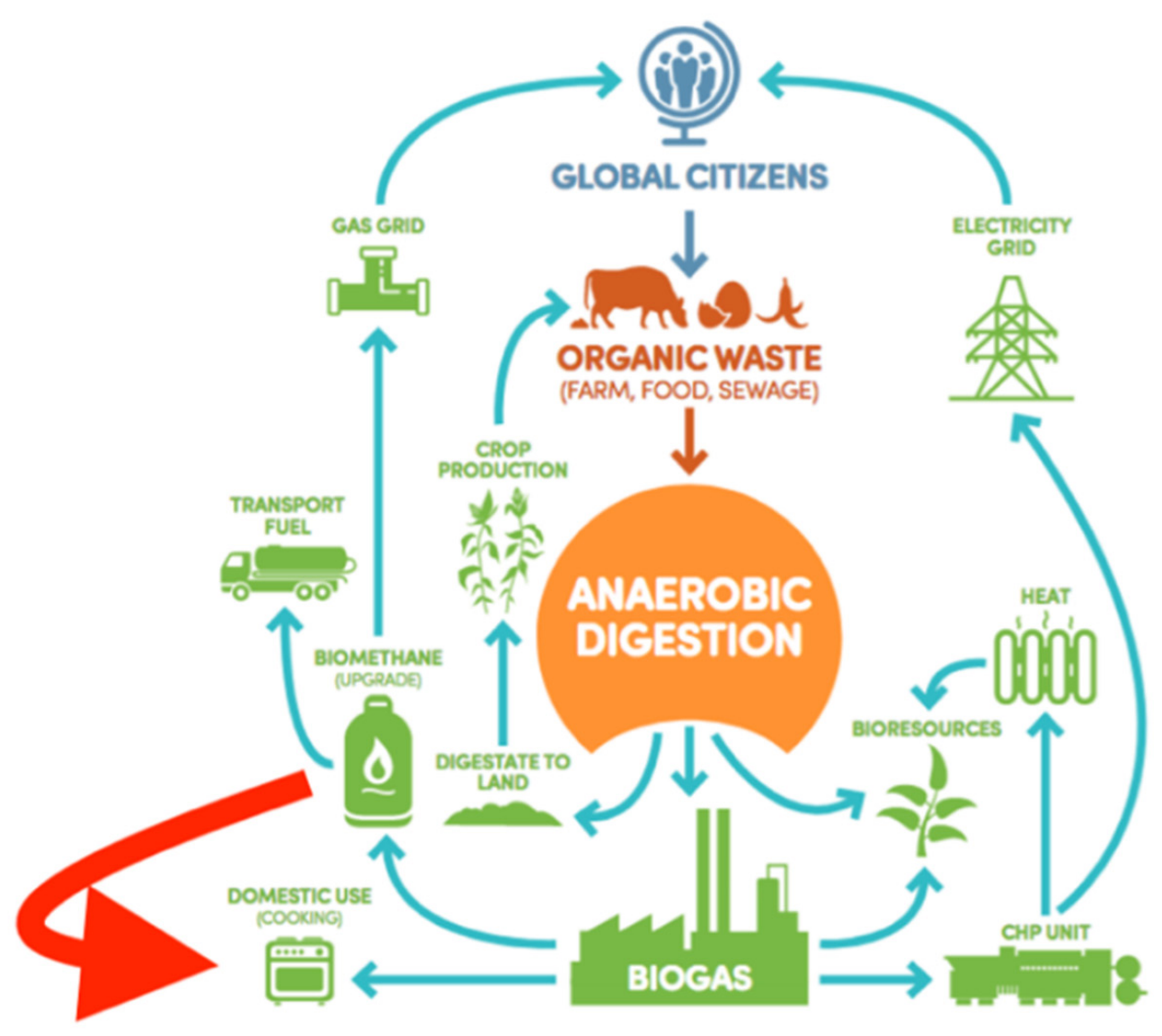

Figure 1. Anaerobic digestion systems and the proposed opportunity for compressed and bottled biogas (modified from [3]).

Due to its versatility and the country specific policy mechanisms to address waste management, renewable energies and climate change, AD and biogas uses have been promoted in several countries [4]. The European Union has included biogas as part of its Renewable Energy Directive [5], the Directive on Alternative Fuels Infrastructure [6] and as part of its climate change commitment [7], and it was estimated that biogas will contribute $25 \%$ to the 2020 EU-28 renewable energy targets $[1,8]$. China has had a long history of biogas utilisation that, since 2003, has been heavily sponsored through policies and incentives, resulting in a considerable uptake of biogas technologies at a small and a large scale. It has been reported that in China in 2013, there were 43 million smallscale (family) users of biogas and 10,000 large-scale biogas projects [9]. India has also promoted the use of biogas in rural areas since the early 1970s, through policies promoting off-grid energy, the National Biogas and Manure Management Programme and a national programme for energy recovery from municipal solid, industrial and agricultural waste. It has been reported that total biogas production in India is 2.07 billion $\mathrm{m}^{3}$ / year, from an estimated potential of 29-48 billion $\mathrm{m}^{3}$ /year [10].

$\mathrm{AD}$ is also seen as a waste management and bioenergy opportunity for Africa. Initiatives in several African countries have been reviewed and have highlighted barriers to implementation, such as investment costs for digester systems, understanding of feedstock availability and a lack of promotion/understanding of the technology [11]. There has been a particular focus on small-scale AD in Africa, for rural communities where reliance on traditional fuels (wood and charcoal) is prevalent. Whilst the use of traditional fuels in SSA may be seen as a contributing factor to global warming, resulting from combustion emissions (0.4-1.2\% of global $\mathrm{CO}_{2}$ (eq) emissions) and black carbon emissions (6\% of global black carbon emissions) and the fuel sourcing contributing to deforestation (consumption of $>300$ million tons of wood, including wood harvested for charcoal production), tradi- 
tional fuel use is also having a significant impact on the health and well-being of those communities that rely on their use. A report by The World Bank states that 900 million households in Sub-Saharan Africa (SSA) will still rely on traditional cooking stoves in 2020 and that 600,000 deaths per year can be attributed directly to the smoke generated by traditional cooking stoves and the fuels used [12]. Further health issues associated with household air pollution (HAP) are also highlighted, and it is reported that, globally, HAP-related deaths account for more deaths than HIV/AIDs and malaria combined. The promotion of cleaner, more efficient cooking options for developing countries has, for many years, focused on the design of cook stoves, which still rely on traditional energy sources; however, alternative energy options such as ethanol, liquefied petroleum gas (LPG) and biogas have also been promoted as affordable, clean energy alternatives for cooking in the home, to replace traditional fuels.

At the household level, finding simple solutions to replace traditional fuels for cooking, heating and lighting is an on-going challenge, particularly in developing countries where both energy access and energy affordability are inadequate and are closely linked. The bottling of biogas has been suggested as an option for providing accessible, renewable, clean energy sources that could be delivered to the home in the same manner as Compressed Natural Gas (CNG) (in the context of this paper, CNG is used to describe methane from fossil resources, whilst bioCNG is used to denote compressed biomethane derived from organic waste AD systems) [13]. However, there are technical issues that must be overcome to make this a practical solution, most of which will add to the cost of producing the fuel and the affordability to households. Various authors in India have explored the potential of adopting bottling techniques for biogas, and implied that there are commercial applications underway [13-15]. However, there is limited evidence in the public domain, and it is evident that the bottling technology has not yet taken off at scale.

This paper presents the first scoping study of the opportunities for bottled biogas as a clean cooking option in Africa. Set within case study contexts in Ghana and Uganda, the study undertakes a techno-economic assessment of a novel technology for small-scale and low-cost biogas clean-up into biomethane, and subsequent compression into small bottles, that is suitable as a clean cooking fuel. The study also sought to understand the barriers and key issues to be addressed, to enable the opportunity.

\section{Literature Review for Anaerobic Digestion and Biogas Bottling}

$\mathrm{AD}$ is a naturally occurring process in the recycling of organic matter in the environment. In the absence of oxygen, specific categories of anaerobic (putrefactive) bacteria digest organic matter, producing biogas as a by-product of their metabolism. AD may occur in any oxygen depleted environment, e.g., water-logged soils (including, e.g., paddy fields), water bodies, the digestive systems of other living organisms [16], as well as in landfill and other waste storage systems (e.g., farmyard effluent and manure storage, palm oil mill effluent (POME) ponds). Managed AD systems can result in energy provision from the methane-rich biogas; a reduction in the volume, mass and toxicity of wastes (as the input substrate); and a beneficial slurry that can be used as a biofertilizer and soil conditioner to improve crop yields. The composition of biogas is highly dependent on the organic substrate and the conditions under which the process takes place. A biogas' composition can include methane $\left(\mathrm{CH}_{4}\right), 50-70 \%$; carbon dioxide $\left(\mathrm{CO}_{2}\right), 25-50 \%$; nitrogen $\left(\mathrm{N}_{2}\right), 0-10 \%$; hydrogen $\left(\mathrm{H}_{2}\right), 0-1 \%$; oxygen $\left(\mathrm{O}_{2}\right), 0-2 \%$ with traces of hydrogen sulphide $\left(\mathrm{H}_{2} \mathrm{~S}\right)$ and water vapour [17]. The chemical composition of the organic substrate is also an influencing factor on the AD conversion rates and yields, and the final composition of the slurry effluent [18]. Biogas yields can range from 10-1200 $\mathrm{m}^{3}$ per ton of fresh matter (from animal slurries and dedicated crops to food wastes and fats).

The chemistry of the AD process has been widely described in the literature [11,16-20] and occurs during four processes, which are carried out by various groups of bacteria that work together during the decomposition of organic materials, i.e., hydrolysis, acidogenesis, acetogenesis and methanogenesis. The AD process and composition of the raw biogas 
outcome is dependent on the type of feedstock, most importantly, the carbon (C) and nitrogen $(\mathrm{N})$ content and the $\mathrm{C} / \mathrm{N}$ ratio [21]. It can also be affected by the presence of toxic compounds that may be present in waste materials (e.g., high ammonia content, soluble copper, zinc, nickel, mercury and chromium salts; pesticides and synthetic detergents [22]). The AD process is also influenced by the composition of the bacterial flora used to initiate the process, which are, in turn, influenced by process parameters such as temperature (i.e., mesophilic bacteria predominate at $30-40{ }^{\circ} \mathrm{C}$, whilst thermophilic bacteria function between $50-60{ }^{\circ} \mathrm{C}$ ) and $\mathrm{pH}$ (i.e., a low $\mathrm{pH}$ can inhibit bacterial function). Numerous types of AD systems exist, and the type and design of the AD process facilities will depend on the application and scale of the system required (e.g., small-scale household/farm waste management or large-scale municipal waste treatment (solid or water waste)), slurry treatment, agro-processing waste and food waste treatment. AD facility designs and the process parameters that affect biogas production are well reported in the literature [2,19-21,23].

Biogas can be used directly as a cooking fuel in its "raw" state, as well as for the provision of heat and light for local requirements (e.g., direct process heat in agro-processing facilities from which the waste is derived). Small-scale household and/or farm waste management in India and China has demonstrated the use of AD technology for direct use in cooking (without biogas clean-up) $[9,10]$. Large-scale waste treatment of solid or liquid waste, slurry treatment, agro-processing and food waste has also become commonplace in several countries, providing electricity (using biogas in CHP), a direct injection of biomethane to gas grids or use as a transport fuel. However, these larger scale applications rely on access to the existing infrastructure for electricity or gas distribution. In many rural areas, such infrastructure may not exist and would be costly to deploy; therefore, providing a means of utilising biogas in a transportable format would allow distribution and access to a clean cooking fuel to more widely dispersed rural communities.

As a result of the composition of raw biogas, downstream uses may require the removal of harmful contaminants (e.g., the combustion of $\mathrm{H}_{2} \mathrm{~S}$ in biogas causes corrosion in downstream equipment due to the formation of acids, as well as being detrimental to human health $[24,25])$ and the removal of $\mathrm{CO}_{2}$ to increase the energy concentration $\left(>98 \% \mathrm{CH}_{4}\right)$ to be most effective [26]. Biogas purification technologies are well documented in the literature and can be considered according to their function, i.e., biogas cleaning is the removal of toxic, harmful or corrosive contaminants, whilst biogas upgrading is the improvement of the calorific/heating value by the removal of $\mathrm{CO}_{2}$ and water vapour [27]. Different processes for biogas clean-up and upgrading have been designed to target specific contaminants related to the starting feedstock or the removal of targeted gases. In the literature, biogas cleaning processes are variously referred to according to the target gases for removal or by the system/mechanism used for separation. Biogas cleaning and upgrading technologies include the removal of unwanted components in raw biogas by physical or chemical absorption; adsorption on solids; physical separation (membrane separation), cryogenic separation and chemical conversion [13,28]. Gas scrubbing systems often refer to the absorbents used for the removal of unwanted gases, e.g., water scrubbing, acidic scrubbing, solvent scrubbing and amine scrubbing [24,29,30].

The technologies used for the clean-up and upgrading of biogas will depend on the AD substrate composition and resulting biogas composition, but also on the end use of the biogas, the scale of biogas production and on the technical specifications for downstream systems [31]. The cost of the biogas clean-up and upgrading technology plus the installation, energy and operation and management (O\&M) costs will affect the feasibility of the end use application. A summary of biogas upgrading technologies in Europe [32] suggests that high pressure water scrubbing is the most suitable for small scale biogas upgrading, due to the low installation and maintenance costs and high yields of high purity biogas. Water scrubbing is also highlighted for its economic viability at a larger scale, where biogas upgrading is aimed at maximizing methane content and purity, and energy efficiency [28].

In countries that have promoted AD for waste management and energy provision, feedstock availability and biogas production may be intermittent but can be managed 
through the existing energy infrastructural capacity, by biogas storage or by feedstock storage and regulation $[33,34]$. In countries where no such infrastructure exists, there may be limited options for further downstream uses of biogas once the immediate needs of a household or facility have been met. Compression and bottling could provide a decentralised option to utilise biogas [14], allowing for the transportability and storage of biogas; however, raw biogas would require a cost effective process for cleaning and upgrading to maximise the energy content to be effective.

Applying an appropriate gas purification technology to AD systems in developing countries may also need to take into account the local conditions for customisation of technologies, e.g., warmer climates might require a cooling instead of a heating functionality, furthermore lower cost construction materials, manufacturing and re-development may make technologies more attractive/applicable. A new water scrubbing system has been developed by Engas UK Ltd. (a small-medium enterprise located in West Sussex, UK), which combines biogas scrubbing, drying and compression into one single step, enabling significant reductions in capital costs and an improved energy efficiency. Figure 2 shows the system. The technology has secured several rounds of competitive research funding from Innovate UK, and a version of it is already on the market and in commercial use, but it is not configured for the cooking application investigated here.

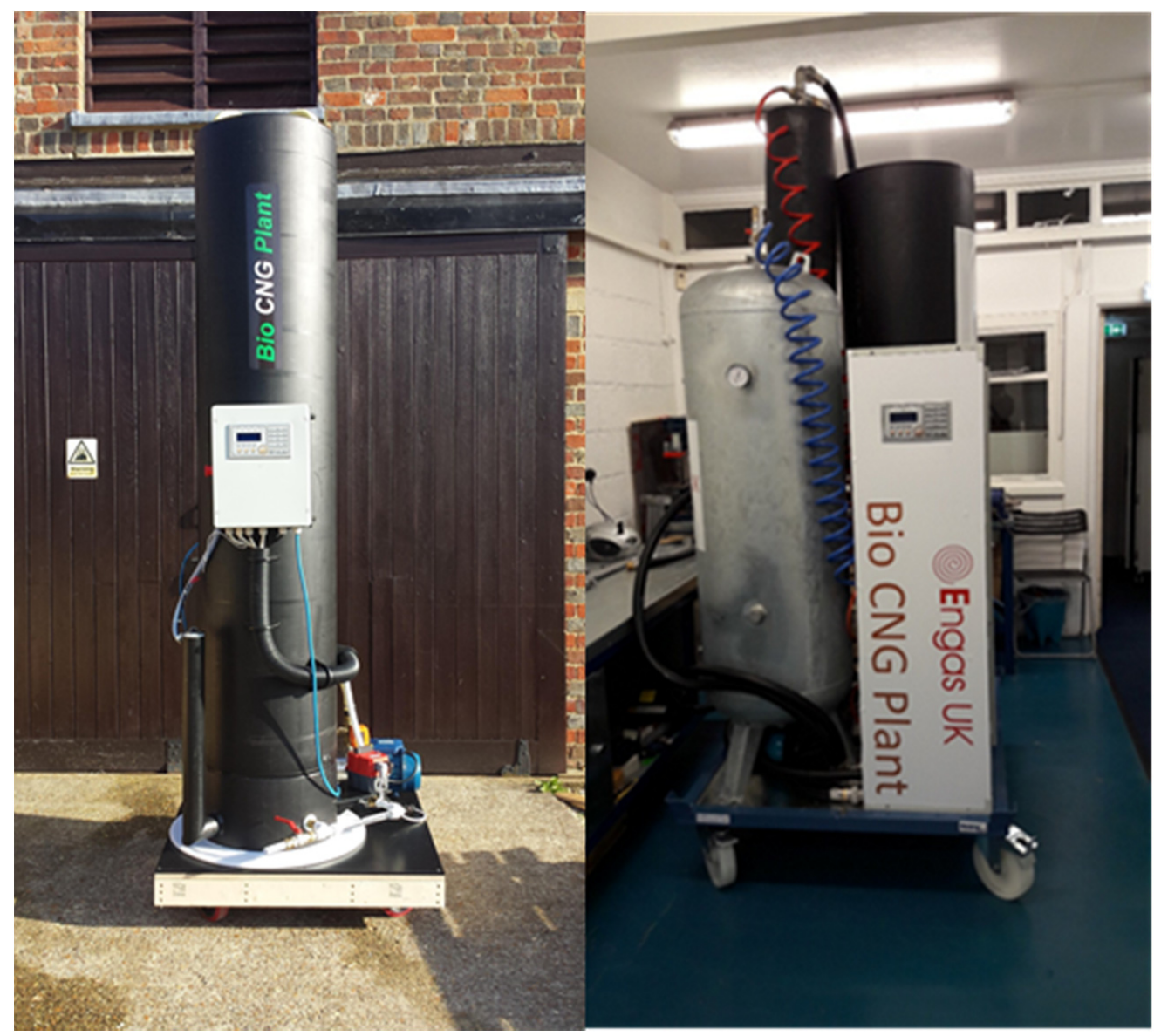

Figure 2. Engas UK's bioCNG plant.

The technology is light weight and, by combining the three key stages of conventional water scrubbing, i.e., the pre-compression, scrubbing and drying of biogas, offers a biogas upgrading technology that could be applied to smaller scale agro-processing facilities, e.g., dairy and poultry farms, cassava/starch processing industries or hotel/university campuses that have deployed AD as a means of dealing with waste. In the context of this study, it may also be suitable for larger scale facilities (e.g., sugarcane or palm oil 
processors) that currently deploy AD for waste management and produce more biogas than is used for local requirements. Due to a lack of downstream infrastructure for biogas uses, biogas may then be flared to the atmosphere.

\section{Case Studies on Anaerobic Digestion and Biogas Use}

The opportunities for AD are strongly affected by the characteristics of the feedstock available, and the opportunities for new clean cooking options depend on the characteristics of the existing fuels in use. It is, therefore, important to set the analysis in specific contexts and then to explore how outcomes are affected by different local conditions. For this initial feasibility study in Africa, two case study countries were selected, Ghana and Uganda. Each offers a variety of organic feedstock options, but AD and commercial scale biogas activities are further advanced in Ghana. Importantly for this analysis, the two countries differ significantly in the economics of the key competing clean cooking fuel, LPG, with prices in Uganda more than twice those in Ghana.

\subsection{Ghana}

Ghana's economy is reliant on a strong agricultural sector that is comprised of five major subsectors, i.e., food crops (59.9\%), livestock $(7.1 \%)$, fisheries $(7.6 \%)$, cocoa $(14.3 \%)$ and forestry (11.1\%) [35]. These sub-sectors generate waste at the point of production (i.e., field/farm residues) and at the point of processing (i.e., process residues and by-products and wastewater). Additionally, municipal organic waste (from households, markets, catering, etc) and human organic waste require management to which AD systems could be applied [36,37]. Biomass is traditionally used in Ghana as a fuel for household needs, comprising 90-95 percent of wood fuels in the forms of firewood and charcoal [38]. Large and untapped biomass resources indicate that Ghana has significant bioenergy potential and number of scientific studies indicate the availability of biomass resources for biogas production, as summarised in Table $1[37,39,40]$.

Table 1. Theoretical biogas potential from various organic waste sources in Ghana [37].

\begin{tabular}{cccc}
\hline Residue Type & Quantity (Mt) & Biogas $\mathbf{( \mathbf { M m } ^ { \mathbf { 3 } } \mathbf { C } \mathbf { H } _ { \mathbf { 4 } } / \text { Year) }}$ & Energy (PJ/Year) \\
\hline Field crop residues & 20 & 1600 & 57 \\
Process residues & & 750 & 27 \\
Wood waste & 0.35 & 19 & 0.63 \\
Animal manure & 2860 & 100 & 3.6 \\
Municipal solid waste & 2.1 & 230 & 8.4 \\
Municipal liquid waste & 0.56 & 17 & 0.61 \\
Total & 2883 & 2716 & 97.2 \\
\hline
\end{tabular}

Specific agro-processing industries in Ghana that have been reviewed include oil palm processing (where untreated Palm Oil Mill Effluent (POME) is a known environmental issue due to the methane emissions); the fruit processing industry; cocoa processing; starch production from cassava; livestock farming and waste from abattoirs and slaughterhouses (Table 2).

Whilst there is opportunity for the development of AD technologies in Ghana, these have largely been promoted to manage waste rather than for energy provision [45]. AD opportunities are largely promoted in small-scale applications for institutions, industries and communities, where biogas can be used directly for cooking, process heat and lighting. Research into the development of biogas in Ghana is ongoing (e.g., [46-48]), and the following market segments were identified as investment opportunities for small-scale applications such as the bottling biogas technology presented here:

- Design and installation of agricultural waste-to-energy or feedstock to energy systems for oil palm plantations, food/fruit processing, abattoirs and packaging companies;

- Biogas lanterns and generators for rural communities-sale of equipment components to landlords and estate companies with biogas digesters; 
- Wastewater/effluent/sludge to energy using AD from starch factories, breweries, etc;

- Extraction, cleaning, storage and use of landfill gas from various open dumps for energy and electricity;

- $\quad$ Combined faecal sludge and municipal solid waste to energy systems.

Table 2. Theoretical biogas potentials from agro-processing in Ghana.

\begin{tabular}{|c|c|c|}
\hline Agro-Processing Industry & $\begin{array}{c}\text { Biogas } \\
\left(\mathrm{Mm}^{3} \mathrm{CH}_{4} / \text { Year }\right)\end{array}$ & Ref. \\
\hline Oil Palm POME & 0.0118 & [41] \\
\hline Fruit processing (mango and pineapple) & $5.32-7.70$ & {$[42]$} \\
\hline Cocoa processing & 4.72 & [42] \\
\hline Starch production (cassava) & 6.13 & * pers comm \\
\hline Livestock farming & 305.26 & {$[43,44]$} \\
\hline Livestock processing (data from largest 2 abattoirs) & 0.0179 & [42] \\
\hline Total & est. 321.46 & \\
\hline
\end{tabular}

* Factory manager at starch plant.

\subsection{Uganda}

The agricultural industry also plays a significant role in Uganda, accounting for $24.9 \%$ of the GDP in 2016/2017 [49]. As with Ghana, organic wastes and residues can be divided into field/farm and processing residues, and have been assessed with a view to bioenergy use and potential $[50,51]$. The key industries in agro-processing account for $61 \%$ of gross output for the manufacturing sector in Uganda and include the processing of meat, fish, vegetable oils and fats; dairy products; coffee processing; grain milling; tea processing; sugar manufacturing; bakery and the manufacture of other food products; the manufacture of beverages and tobacco; cotton ginning and the manufacture of textiles and leather products [52]. Whilst no specific studies have been carried out on the biogas/energy potential across the agro-industries, agro-processors have been adopting AD as a means of conforming to The National Environment (Standards for Discharge of Effluent into Water or on Land) Regulations (S.I. No. 4 of 1999). Biogas is generally used for on-site process heat and energy requirements, but often it is not optimised, and excess biogas may be flared to the atmosphere. The estimates of biogas potential for this study were based on annual production rates for primary products and wastewater potential for the sugar processing, dairy processing and fish processing industries [45].

Waste from the livestock industry can also be considered in terms of livestock rearing and livestock processing, and reports suggest a high potential for biogas production (Table 3).

Table 3. Theoretical biogas potential from livestock industry in Uganda.

\begin{tabular}{ccc}
\hline Agro-Processing Industry & Biogas $\mathbf{( \mathbf { M m } ^ { \mathbf { 3 } } \mathbf { C } \mathbf { H } _ { \mathbf { 4 } } / \text { Year) }}$ & Ref. \\
\hline $\begin{array}{c}\text { Livestock farming (cattle, sheep, goats, pigs, poultry) } \\
\text { Livestock processing (estimated biogas production based on } \\
\text { wastewater generated / day from 20 abattoirs in Uganda) } \\
\text { Total }\end{array}$ & 1258.00 & [53] \\
\hline
\end{tabular}

Municipal waste and sewerage also hold great potential for energy recovery in Uganda, using $\mathrm{AD}$ as a conversion technology; however, currently there is no significant management and capture of these resources [54-56].

Uganda has been part of the African Biogas Partnership Programme and has gained technical experience in the development of small scale AD for domestic use for cooking and lighting, with some uptake for electricity generation [57]. Although widespread uptake of AD technology is still limited in Uganda, it is increasingly of interest to the Ugandan government, and studies on the economics of small scale systems for biogas to electricity demonstrate the attractiveness of the AD biogas proposition [58]. 


\section{Materials and Methods}

A simple techno-economic analysis was undertaken, seeking to compare the cost of cooking using bottled, compressed biomethane (bioCNG) with the most common modern energy source use for cooking in the case study countries, LPG.

The underpinning question is, what would be the simple payback period for an investment in a bioCNG plant, if the resulting bottled gas is sold to households at a price that gives a cooking cost equivalent to that of LPG? Comparison to a popular competitor provides an immediate check on the feasibility of the bioCNG proposition. Further analyses could also consider bottled bioCNG as a replacement for traditional wood fuel and charcoal as cooking fuel options, as well as directly calculating the necessary selling price, or the price target needed for a realistic investment case.

LPG retail prices were assumed to be USD $1.08 / \mathrm{kg}$ in Ghana, i.e., USD 15.66 for a $14.5 \mathrm{~kg}$ standard LPG cylinder [59], and USD 2.6/ kg in Uganda, i.e., USD 37.7 for one $14.5 \mathrm{~kg}$ LPG cylinder [60]. Based on research in other parts of Sub-Saharan Africa, these were assumed to be within a sensible range of common prices subject to exchange rate fluctuations. The only difference in the assumptions in the analysis for Ghana and Uganda was the LPG prices. The overall calculation made therefore compares the price for a certain quantity of LPG with the cost of producing bioCNG with an equivalent energy content. If bioCNG production costs are lower, this provides a net operating profit that is set against the bioCNG plant investment cost to calculate the overall payback on such an investment.

The study assumes that bioCNG cylinders are made of high strength composite material, capable of storing bioCNG at 248 bar. This leads to a similar filled weight to those used for LPG cylinders, to ensure that the cylinder remains convenient for manual handling. However, the energy content in the bioCNG would still be less than half that for an equivalent LPG cylinder, due to the lower volumetric energy density $\left(\mathrm{kWh} / \mathrm{Nm}^{3}\right)$ of bioCNG (LPG energy density $=13.6 \mathrm{kWh} / \mathrm{kg}$. At $97 \% \mathrm{CH}_{4}$ purity, bioCNG energy density $=12.89 \mathrm{kWh} / \mathrm{kg}$; bioCNG volumetric energy density $=9.67 \mathrm{kWh} / \mathrm{Nm}^{3}$ ) and therefore more frequent refilling will be required. Alternative filling using a larger cascade of cylinders with mechanical lifting and transport/retail arrangements could be considered for hotels and restaurants to ameliorate the impact on the user of needing to refill cylinders more frequently, or to allow for higher capacity cylinders to be used, but such considerations were not taken into account in this initial assessment.

A wide variety of feedstocks for AD are available in Ghana and Uganda (as reported in Section 3), e.g., sugar mill spent-wash/press-mud, animal manure, cassava starch pulp, market vegetable waste, fish processing waste, etc. Some facilities already utilise AD systems to manage waste and use biogas for internal process energy, but excess biogas may be flared at a cost to the environment. Silent venting of biogas or landfill gas into the atmosphere is more widespread than is acknowledged officially; in many cases the business and regulatory driver for AD may be wastewater treatment rather than energy recovery [61]. Flaring is better than venting but, again, it is not openly acknowledged, as flaring glaringly highlights the operational shortcomings of biogas plants. Therefore, this is an opportunity for portable mobile-biogas upgrader plants to capture stranded biogas from a number of sites converted into bottled bioCNG.

It is assumed that appropriate feedstock for AD systems is available for free. This assumption reflects the situation that institutions generating such wastes will typically incur costs in disposal or other management, and thus might be willing to provide feedstock at zero cost. Similarly, no value for the bioCNG system has been included to reflect any 'gate-fees' for taking wastes away. For this first analysis, it was assumed that feedstock reflects neither a cost nor a benefit.

Labour and land costs are included, with the assumptions stated in Table 4. These are particularly uncertain, as the cases analysed here are hypothetical and not based in a specific context. However, these costs are critical in the overall cost-benefit of the system. The financial calculations are kept deliberately simple: no discounting is used, and there is no consideration of how the investment might be financed. The only investment performance 
measure used is simple payback period [62], which is calculated by dividing the total capital cost by the net operating profit. Whilst this limits the depth of the analysis, simple payback is widely used as a rule of thumb and screening measure for investments.

Table 4. Summary techno-economic analysis for bioCNG in Ghana and Uganda.

\begin{tabular}{|c|c|c|c|c|c|c|c|}
\hline \multirow{2}{*}{$\begin{array}{l}\text { Key Assumptions and } \\
\text { Outcomes }\end{array}$} & \multirow{2}{*}{ Units } & \multicolumn{2}{|c|}{ Smallest System } & \multicolumn{2}{|c|}{$\begin{array}{l}\text { Medium-Scale } \\
\text { System }\end{array}$} & \multicolumn{2}{|c|}{ Largest System } \\
\hline & & Uganda & Ghana & Uganda & Ghana & Uganda & Ghana \\
\hline Plant capacity & $\begin{array}{c}\mathrm{Nm}^{3} / \mathrm{h} \text { raw biogas } \\
\text { output }\end{array}$ & 3.00 & 3.00 & 10.00 & 10.00 & 25.00 & 25.00 \\
\hline $\begin{array}{l}\text { LPG refill price } \\
\text { (14.5 kg cylinder })\end{array}$ & USD/cylinder & 37.70 & 15.66 & 37.70 & 15.66 & 37.70 & 15.66 \\
\hline $\begin{array}{l}\text { Price bioCNG (equivalent } \\
\text { energy content basis) }\end{array}$ & USD $/ \mathrm{kg}$ BioCNG & 2.46 & 1.02 & 2.46 & 1.02 & 2.46 & 1.02 \\
\hline $\begin{array}{l}\text { Volume agro-waste } \\
@ 12 \text { kg/ } \mathrm{Nm}^{3} \text { raw biogas }\end{array}$ & kg/day & 864.00 & 864.00 & 2880.00 & 2880.00 & 7200.00 & 7200.00 \\
\hline Price of feedstock & $\mathrm{USD} / \mathrm{kg}$ & 0.00 & 0.00 & 0.00 & 0.00 & 0.00 & 0.00 \\
\hline $\begin{array}{l}\text { Number of bioCNG } \\
\text { cylinders produced }\end{array}$ & cylinders/day & 4.73 & 4.73 & 15.76 & 15.76 & 39.40 & 39.40 \\
\hline $\begin{array}{l}\text { Equiv. } 14.5 \text { LPG cylinders } \\
\text { replaced by bioCNG }\end{array}$ & cylinders/day & 2.01 & 2.01 & 6.71 & 6.71 & 16.77 & 16.77 \\
\hline Income from sale of bioCNG & USD/day & 75.87 & 31.52 & 252.90 & 105.05 & 632.25 & 262.63 \\
\hline $\begin{array}{l}\text { Compost produced assuming } \\
10 \% \text { solid }\end{array}$ & $\mathrm{kg}$ /day compost & 86.40 & 86.40 & 288.00 & 288.00 & 720.00 & 720.00 \\
\hline $\begin{array}{l}\text { Market price of compost } \\
\text { (semi dry) }\end{array}$ & USD $/ \mathrm{kg}$ compost & 0.06 & 0.06 & 0.06 & 0.06 & 0.06 & 0.06 \\
\hline Income from compost sales & USD/day compost & 4.80 & 4.80 & 16.00 & 16.00 & 40.00 & 40.00 \\
\hline $\begin{array}{c}\text { Total income } \\
\text { (bioCNG + fertiliser) }\end{array}$ & USD/year & 26,554 & 11,030 & 88,515 & 36,768 & 221,287 & 91,919 \\
\hline Capex of AD plant & USD & 16,667 & 16,667 & 30,556 & 30,556 & 58,333 & 58,333 \\
\hline $\begin{array}{c}\text { Capex of bioCNG upgrader and } \\
\text { compressor }\end{array}$ & USD & 25,000 & 25,000 & 35,000 & 35,000 & 60,000 & 60,000 \\
\hline $\begin{array}{c}\text { Capex of single gas cylinder } \\
\text { Total capital cost }\end{array}$ & $\begin{array}{l}\text { USD } \\
\text { USD }\end{array}$ & $\begin{array}{c}663 \\
51,064\end{array}$ & $\begin{array}{c}663 \\
51,064\end{array}$ & $\begin{array}{c}663 \\
96,879\end{array}$ & $\begin{array}{c}663 \\
96,879\end{array}$ & $\begin{array}{c}663 \\
196,643\end{array}$ & $\begin{array}{c}663 \\
196,643\end{array}$ \\
\hline $\begin{array}{l}\text { Farm owner-operator wage, } \\
£ 833 / \text { month }\end{array}$ & USD/year & 0 & 0 & 10,000 & 10,000 & 10,000 & 10,000 \\
\hline $\begin{array}{l}\text { Labour cost: } £ 150 / \text { month } \\
\times 12 \text { months } \times \text { no. people }\end{array}$ & USD/year & 5000 & 5000 & 7500 & 7500 & 10,000 & 10,000 \\
\hline $\begin{array}{l}\text { Land lease cost } \\
\text { Total labour and land costs }\end{array}$ & $\begin{array}{l}\text { USD/year } \\
\text { USD/year }\end{array}$ & $\begin{array}{c}0 \\
5000 \\
\end{array}$ & $\begin{array}{c}0 \\
5000 \\
\end{array}$ & $\begin{array}{c}6944 \\
24,444 \\
\end{array}$ & $\begin{array}{c}6944 \\
24,444 \\
\end{array}$ & $\begin{array}{l}13,889 \\
33,889\end{array}$ & $\begin{array}{l}13,889 \\
33,889\end{array}$ \\
\hline Electricity rate (Uganda) & USD/kWh & 0.21 & 0.21 & 0.21 & 0.21 & 0.21 & 0.21 \\
\hline $\begin{array}{l}\text { Energy use by biogas } \\
\text { upgrader + compressor }\end{array}$ & $\mathrm{kWh} / \mathrm{Nm}^{3}$ raw biogas & 0.50 & 0.50 & 0.50 & 0.50 & 0.50 & 0.50 \\
\hline $\begin{array}{l}\text { Cost of electricity for } \\
\text { bioCNG + compressor }\end{array}$ & USD/day & 7.50 & 7.50 & 25.00 & 25.00 & 62.50 & 62.50 \\
\hline $\begin{array}{l}\text { Servicing and maintenance cost } \\
@ 10 \% \text { of capex }\end{array}$ & USD/year & 5106 & 5106 & 9688 & 9688 & 19,664 & 19,664 \\
\hline $\begin{array}{c}\text { Total overhead and } \\
\text { operating cost }\end{array}$ & USD/year & 12,731 & 12,731 & 42,882 & 42,882 & 75,428 & 75,428 \\
\hline Net operating profit & USD/year & 13,823 & -1701 & 45,632 & -6115 & 145,858 & 16,491 \\
\hline Payback period & years & 3.69 & -30.02 & 2.12 & -15.84 & 1.35 & 11.92 \\
\hline
\end{tabular}

The most appropriate scale of cooking fuel production is a key question. For example, in exploring the opportunities for producing butane/propane (a "bioLPG") from wastes in Africa, reference [63] discusses the dilemma about whether to go for a large-scale production plant, with the economies of scale in a process plant, but greater difficulty (and likely higher costs) of the feedstock gathering and the distribution of the final product, or to focus on a small scale and more highly distributed production, closer to feedstock and fuel users.

Reference [64] identifies the two most significant factors in the cost advantage for larger scale biomethane production as the capital cost of a processing plant; and the 
labour costs for plant operations. Key to both of these is process complexity-the Engas UK technology is designed to be relatively simple, using off-the shelf components and minimising maintenance requirements. If this approach can offer cost effective bioCNG production at a scale suited to a distributed model, it offers the potential to access a wider range of smaller feedstock sources, helping overcome the traditional view of economies of scale in biogas production [65] and to supply cooking fuels to more geographically dispersed users. For this scoping study, three likely scales of plant are assessed, from a very small plant that could refill only a handful of bottles for household use per day, up to a medium scale commercial scale.

\section{Results}

Table 4 shows some of the key assumptions used in the techno-economic analysis, and the economic results. The complete model is included in the Supplementary Materials.

The results show that the use of an innovative biogas cleaning and upgrading technology, implemented for small to medium scale applications, can make bioCNG for cooking a feasible proposition. The modelling compares the costs of producing bioCNG to the prices for an equivalent supply of LPG as a key competing cooking fuel. As such, the results are sensitive to assumptions made on, e.g., the cost of feedstock for the AD system. Given that the only difference in the assumptions in the analysis for Ghana and Uganda was for the retail price of LPG, assumed to be USD $1.08 / \mathrm{kg}$ in Ghana and USD $2.6 / \mathrm{kg}$ in Uganda, the comparison of the payback results shows how sensitive they are to the fuel selling price. For Uganda, all three system sizes achieve payback times below 4 years, and, for the two larger systems, the payback is within the range of one to two years. However, for Ghana, only the largest system achieves payback within the realistic lifetime of the equipment, and the smallest system will not payback at all.

\section{Discussion}

$\mathrm{AD}$ technology is increasingly being promoted as a means of reducing the greenhouse gas emissions associated with current management systems of organic waste (i.e., landfill, infield burning of crop residues, open storage lagoons etc). In Africa, AD has been promoted at the smaller scale, to address clean energy access for cooking, heating and lighting, with varied success. AD systems and the considered use of the biogas and digestate co-products can be seen to address key elements of the United Nations Framework Convention on Climate Change (UNFCCC) Sustainable Development Goals (SDGs), e.g., directly, SDGs 7 (affordable and clean energy), 12 (responsible consumption and production) and 13 (climate action); and indirectly, SDGs 2 (zero hunger) and 6 (clean water and sanitation), depending on the organic feedstock used.

From the literature, and a field and market review of current biogas activities in Ghana and Uganda, it was clear that there is a huge potential for the deployment of $\mathrm{AD}$, provided that technical hurdles can be overcome, and the regulatory environment supports its deployment. The use of biogas, especially as the scale of AD facilities increases, requires further consideration of the infrastructure for both the collection of organic waste and the end-use and distribution of the biogas (or appropriate energy carrier). A lack of infrastructure in rural areas may be a key barrier to deploying AD systems and maximising biogas use, especially in areas with lower population densities. This study investigated the $\mathrm{AD}$ opportunity in rural agrarian communities (i.e., where agricultural co-products may provide centralised organic waste) and in urban communities where agro-processing waste, municipal waste and sewerage all require better waste management.

There is considerable uncertainty over the appropriate parameter values throughout the analysis. For the next steps in the study of the feasibility of these technologies, a better understanding is required of the local uses and management of the organic feedstocks/waste, in terms of competing uses for bioresources and biogas; the priorities and benefits of managing residues and wastes (for the sake of better waste management and the reduction in the environmental impacts of unmanaged waste) and for the provision of 
clean energy; consumer preferences in introducing a new bioCNG clean cooking fuel (i.e., affordability, frequency of use and applicability to existing household regimes/cooking practices); and the markets and distribution of the bottled biogas product, as well as legislation on the health and safety of bottled gases in Ghana and Uganda. The analysis in this paper has mainly focused on the economic and financial indicators (price factors) of the supply side, without exploring other aspects on the demand side. Investigations of consumer attitudes and behaviours (acceptability, intentions and willingness to pay) towards bottled bioCNG in both countries will be important as part of future activities to support investment and policy decisions.

In relation to bio- $\mathrm{CO}_{2}$, it is also worth mentioning that the value associated with bio$\mathrm{CO}_{2}$ as a "free" by-product of the biogas-upgrading process has not been considered in the financial pay-back calculation in this paper. However, $\mathrm{CO}_{2}$ has commercial value for use in greenhouses for an enhanced crop production (e.g., growing tomatoes or leafy vegetables), in wastewater treatment for the $\mathrm{pH}$ control of sewage, for dry ice in cold storage units and as a carbonating agent in beverage industries. Engas UK currently buys industrial grade $\mathrm{CO}_{2}$ from a leading gas supplier (BOC) for the calibration of their biogas-upgraders at about USD 54 for $5.9 \mathrm{~kg} \mathrm{CO}_{2}$, i.e., at more than USD 9/ $\mathrm{kg} \mathrm{CO}_{2}$. Biogas contains about $35-40 \% \mathrm{CO}_{2}$ that will be separated during upgrading; therefore, as an example, a $10 \mathrm{Nm}^{3} / \mathrm{h}$ raw biogas upgrader will produce up to $165 \mathrm{~kg}$ of bioCO $\mathrm{CO}_{2} /$ day with a potential retail value of up to USD 1500/day at the reported UK prices. The additional cost of filtering $\mathrm{CO}_{2}$ and bottling it is worth considering for providing a circular economy solution integrating waste, energy, cooking fuel, transport fuel, crops and fertiliser enabled by this portable biogas upgrading technology.

\section{Conclusions}

This study aimed to specifically address SDG7, considering compressed bottled biomethane (bioCNG) as a clean cooking option, in line with the cooking options that favour the use of bottled LPG as a cleaner cooking fuel (in terms of stove design, bottled gas distribution network, etc.). The project sought to understand the opportunities for bioCNG for cooking in Ghana and Uganda based on the potential biogas availability, the key technical and economic considerations for the opportunity (requirement for further downstream processing of biogas) and the key issues that would need to be addressed to enable the development of bioCNG as a clean cooking fuel.

A general conclusion of the techno-economic modelling undertaken is that, where competing fuel prices are relatively high, a bioCNG system could be a viable proposition at even a small- to medium-scale. This analysis shows the importance of policies supporting the development of renewable energies, including $\mathrm{AD}$ and biogas provision, as policies and environmental regulations affect both the costs for feedstocks and the prices for competing energy types.

Supplementary Materials: The following are available online at https:/ /www.mdpi.com/article/10 .3390/en14133856/s1, Table S1: Techno-economic analysis for bioCNG in Ghana and Uganda.

Author Contributions: Conceptualization, M.L. and M.J.B.; investigation, F.K., E.T. and R.O.; writing-original draft preparation, M.L., M.J.B., F.K., E.T. and A.R.; writing-review and editing, J.S. and R.M. All authors have read and agreed to the published version of the manuscript.

Funding: This research was funded by a QR GCRF grant from Research England to the University of Surrey, with additional matched funding from Engas UK Ltd and from the Modern Energy Cooking Services (MECS) programme, which is funded by UK Aid (GB-GOV-1-300123).

Acknowledgments: Amit Roy acknowledges the support from the School of Energy and Electronic Engineering, the University of Portsmouth, PO1 3DJ, UK where he works as a Senior Lecturer.

Conflicts of Interest: The authors declare no conflict of interest. 


\section{References}

1. Miltner, M.; Makaruk, A.; Harasek, M. Review on Available Biogas Upgrading Technologies and Innovations towards Advanced Solutions. J. Clean. Prod. 2017, 161, 1329-1337. [CrossRef]

2. Weiland, P. Biogas Production: Current State and Perspectives. Appl. Microbiol. Biotechnol. 2010, 85, 849-860. [CrossRef]

3. Jain, S. Global Potential of Biogas; World Biogas Association: London, UK, 2019.

4. Vasco-Correa, J.; Khanal, S.; Manandhar, A.; Shah, A. Anaerobic Digestion for Bioenergy Production: Global Status, Environmental and Techno-Economic Implications, and Government Policies. Bioresour. Technol. 2018, 247, 1015-1026. [CrossRef]

5. Directive 2009/28/EC of the European Parliament and of the Council of 23 April 2009 on the Promotion of the Use of Energy from Renewable Sources and Amending and Subsequently Repealing Directives 2001/77/EC and 2003/30/EC; European Commission: Brussels, Belgium, 2009.

6. Fuel Quality Directive, Directive 2009/30/EC. Available online: https:/ / www.lexisnexis.co.uk/legal/guidance/fuel-qualitydirective-2009-30-ec-snapshot (accessed on 24 June 2021).

7. Anonymous Second European Climate Change Programme. Available online: https://ec.europa.eu/clima/policies/eccp/ second_en (accessed on 27 June 2019).

8. Scarlat, N.; Dallemand, J.-F.; Fahl, F. Biogas: Developments and Perspectives in Europe. Renew. Energy 2018, 129, 457-472. [CrossRef]

9. Gu, L.; Zhang, Y.-X.; Wang, J.-Z.; Chen, G.; Battye, H. Where Is the Future of China's Biogas? Review, Forecast, and Policy Implications. Pet. Sci. 2016, 13, 604-624. [CrossRef]

10. Mittal, S.; Ahlgren, E.O.; Shukla, P.R. Barriers to Biogas Dissemination in India: A Review. Energy Policy 2018, 112, 361-370. [CrossRef]

11. Roopnarain, A.; Adeleke, R. Current Status, Hurdles and Future Prospects of Biogas Digestion Technology in Africa. Reneww. Sustain. Energy Rev. 2017, 67, 1162-1179. [CrossRef]

12. Kammila, S.; Kappen, J.F.; Rysankova, D.; Hyseni, B.; Putti, V.R. Clean and Improved Cooking in Sub-Saharan Africa: A Landscape Report; The World Bank: Washington, DC, USA, 2014; pp. 1-182.

13. Kapdi, S.S.; Vijay, V.K.; Rajesh, S.K.; Prasad, R. Biogas Scrubbing, Compression and Storage: Perspective and Prospectus in Indian Context. Renew. Energy 2005, 30, 1195-1202. [CrossRef]

14. Harsha, D.N.; Yadwad, A.R.; Nadeem, M.D. Planning and Design for Commercialization of Biogas Bottling Plant for Production of Green and Low-Cost Fuel with Utilization of Biomass Resources. Int. J. Sci. Eng. Res. 2015, 6, 4.

15. Salave, H.S.; Desai, A.D. Design, Development and Experimental Investigation on Various Biogas Upgrading Techniques. IOSR J. Mech. Civ. Eng. 2017, 17, 55-60. [CrossRef]

16. Felton, G.; Lansing, S.; Moss, A.; Klavon, K. Anaerobic Digestion: Basic Processes for Biogas Production; Fact Sheet; University of Maryland: Maryland, MD, USA, 2014.

17. Raja, I.A.; Wazir, S. Biogas Production: The Fundamental Processes. Univers. J. Eng. Sci. 2017, 5, 29-37. [CrossRef]

18. Achinas, S.; Achinas, V.; Euverink, G.J.W. A Technological Overview of Biogas Production from Biowaste. Engineering 2017, 3 , 299-307. [CrossRef]

19. Deepanraj, B.; Sivasubramanian, V.; Jayaraj, S. Biogas Generation through Anaerobic Digestion Process-An Overview. Res. J. Chem. Environ. 2014, 18, 80-93.

20. Zhang, Q.; Hu, J.; Lee, D.-J. Biogas from Anaerobic Digestion Processes: Research Updates. Renew. Energy 2016, 98, 108-119. [CrossRef]

21. Divya, D.; Gopinath, L.R.; Merlin Christy, P. A Review on Current Aspects and Diverse Prospects for Enhancing Biogas Production in Sustainable Means. Renew. Sustain. Energy Rev. 2015, 42, 690-699. [CrossRef]

22. Kwietniewska, E.; Tys, J. Process Characteristics, Inhibition Factors and Methane Yields of Anaerobic Digestion Process, with Particular Focus on Microalgal Biomass Fermentation. Renew. Sustain. Energy Rev. 2014, 34, 491-500. [CrossRef]

23. Meegoda, J.N.; Li, B.; Patel, K.; Wang, L.B. A Review of the Processes, Parameters, and Optimization of Anaerobic Digestion. Int. J. Environ. Res. Public Health 2018, 15, 2224. [CrossRef]

24. Okoro, O.V.; Sun, Z. Desulphurisation of Biogas: A Systematic Qualitative and Economic-Based Quantitative Review of Alternative Strategies. ChemEngineering 2019, 3, 76. [CrossRef]

25. Kuo, J.; Dow, J. Biogas Production from Anaerobic Digestion of Food Waste and Relevant Air Quality Implications. J. Air Waste Manag. Assoc. 2017, 67, 1000-1011. [CrossRef]

26. Mel, M.; Sharuzaman, M.A.H.; Setyobudi, R.H. Removal of $\mathrm{CO}_{2}$ from Biogas Plant Using Chemical Absorption Column. In AIP Conference Proceedings, Vol. 1755, Issue 1; AIP Publishing LLC: New York, NY, USA, 2016; p. 050005.

27. Angelidaki, I.; Treu, L.; Tsapekos, P.; Luo, G.; Campanaro, S.; Wenzel, H.; Kougias, P.G. Biogas Upgrading and Utilization: Current Status and Perspectives. Biotechnol. Adv. 2018, 36, 452-466. [CrossRef]

28. Sahota, S.; Shah, G.; Ghosh, P.; Kapoor, R.; Sengupta, S.; Singh, P.; Vijay, V.; Sahay, A.; Vijay, V.K.; Thakur, I.S. Review of Trends in Biogas Upgradation Technologies and Future Perspectives. Bioresour. Technol. Rep. 2018, 1, 79-88. [CrossRef]

29. Agarwal, A.K.; Shukla, M.K. Portable Biogas Bottling Plant: A Practical Approach for Using Biogas as Transportation Fuel in Rural Areas. Int. J. Oil Gas Coal Technol. 2009, 2, 379-388. [CrossRef]

30. Bauer, F.; Persson, T.; Hulteberg, C.; Tamm, D. Biogas Upgrading-Technology Overview, Comparison and Perspectives for the Future. Biofuels Bioprod. Biorefin. 2013, 7, 499-511. [CrossRef] 
31. Sun, Q.; Li, H.; Yan, J.; Liu, L.; Yu, Z.; Yu, X. Selection of Appropriate Biogas Upgrading Technology-a Review of Biogas Cleaning, Upgrading and Utilisation. Renew. Sustain. Energy Rev. 2015, 51, 521-532. [CrossRef]

32. Biowaste as Feedstock for 2nd Generation, Valorgas Project Final Publishable Summary Report. Available online: https://cordis. europa.eu/docs/results/241334/final1-valorgas-241334-final-publishable-summary-140110.pdf (accessed on 24 June 2021).

33. Lauer, M.; Dotzauer, M.; Hennig, C.; Lehmann, M.; Nebel, E.; Postel, J.; Szarka, N.; Thrän, D. Flexible Power Generation Scenarios for Biogas Plants Operated in Germany: Impacts on Economic Viability and GHG Emissions. Int. J. Energy Res. 2017, 41, 63-80. [CrossRef]

34. Maurus, K.; Ahmed, S.; Kazda, M. Beneficial Effects of Intermittent Feedstock Management on Biogas and Methane Production. Bioresour. Technol. 2020, 304, 123004. [CrossRef] [PubMed]

35. MoFA. Agriculture in Ghana-Facts and Figures. 2012. Available online: http://www.e-agriculture.gov.gh/index.php/2014-0722-14-39-46/agric-facts-and-figures-2012 (accessed on 24 June 2021).

36. Fobil, J.; Carboo, D.; Armah, N. Evaluation of Municipal Solid Wastes (MSW) for Utilisation in Energy Production in Developing Countries. Int J Environ. Technol. Manag. 2005, 5, 76-86. [CrossRef]

37. Kemausuor, F.; Kamp, A.; Thomsen, S.T.; Bensah, E.C.; Østergård, H. Assessment of Biomass Residue Availability and Bioenergy Yields in Ghana. Resour. Conserv. Recycl. 2014, 86, 28-37. [CrossRef]

38. Ghana Energy Commission. Baseline Study of Renewable Energy Technologies in Ghana Vol. 1. Available online: http: / / energycom.gov.gh/rett/files/Baseline-Study-of-Renewable-Energy-Technologies.pdf (accessed on 24 June 2021).

39. Duku, M.H.; Gu, S.; Hagan, E.B. A Comprehensive Review of Biomass Resources and Biofuels Potential in Ghana. Renew. Sustain. Energy Rev. 2011, 15, 404-415. [CrossRef]

40. Mohammed, Y.S.; Mokhtar, A.S.; Bashir, N.; Saidur, R. An Overview of Agricultural Biomass for Decentralized Rural Energy in Ghana. Renew. Sustain. Energy Rev. 2013, 20, 15-25. [CrossRef]

41. Global Network of Regional Sustainable Energy Centers (GN-SEC). REEP Renewabel Energy Policy Framework for Climate Change Mitigation in Ghana. Available online: https://www.gn-sec.net/content/renewabel-energy-policy-framework-climatechange-mitigation-ghana (accessed on 6 December 2019).

42. Ulrike, D.; Karl-Heinz, P.; Navina, G.S. Biogas in Ghana Sector-Analysis of Potential and Framework Conditions. Available online: https://energypedia.info/wiki/File:Biogas_in_Ghana_Sector_-_Analysis_of_Potential_and_Framework_Conditions_ 2014.pdf (accessed on 6 December 2019).

43. MoFA. Livestock Population. Available online: https://mofa.gov.gh/site/directorates/technical-directorates/veterinary-services (accessed on 24 June 2021).

44. Larson, E.D.; Kartha, S. Expanding Roles for Modernized Biomass Energy. Energy Sustain. Dev. 2000, 4, 15-25. [CrossRef]

45. Twinomunji, E.; Kemausuor, F.; Black, M.; Roy, A.; Leach, M.; Oduro, R.; Sadhukhan, J.; Murphy, R. The Potential for Bottled Biogas for Clean Cooking in Africa; Working Paper; Modern Energy Cooking Services Programme, University of Loughborough: Loughborough, UK, 2020.

46. Awafo, E.A.; Amenorfe, J. Techno-Economic Studies of an Industrial Biogas Plant to Be Implemented at Kumasi Abattoir in Ghana. Sci. Afr. 2021, 11, e00712. [CrossRef]

47. Agyenim, F.B.; Dzamboe, P.D.; Mohammed, M.; Bawakyillenuo, S.; Okrofu, R.; Decker, E.; Agyemang, V.K.; Nyarko, E.H. Powering Communities Using Hybrid Solar-Biogas in Ghana, a Feasibility Study. Environ. Technol. Innov. 2020, $19,100837$. [CrossRef]

48. Cudjoe, D.; Nketiah, E.; Obuobi, B.; Adu-Gyamfi, G.; Adjei, M.; Zhu, B. Forecasting the Potential and Economic Feasibility of Power Generation Using Biogas from Food Waste in Ghana: Evidence from Accra and Kumasi. Energy 2021, $226,120342$. [CrossRef]

49. Ministry of Agriculture, Animal Industry and Fisheries. Performance-Report-2016-2017; MAAIF: Entebbe, Uganda, 2018.

50. Okello, C.; Pindozzi, S.; Faugno, S.; Boccia, L. Bioenergy Potential of Agricultural and Forest Residues in Uganda. Biomass Bioenergy 2013, 56, 515-525. [CrossRef]

51. Gebrezgabher, S.A.; Amewu, S.; Taron, A.; Otoo, M. Energy Recovery from Domestic and Agro-Waste Streams in Uganda: A Socioeconomic Assessment; Technical Report; CGIAR Research Program on Water, Land and Ecosystems, International Water Management Institute: Giza, Egypt, 2016.

52. Uganda Bureau of Statistics (UBOS). Report on the Annual Business Inquiry, 2006/2007; Technical Report; UBOS: Kampala, Uganda, 2010.

53. Owusu, P.A.; Banadda, N. Livestock Waste-to-Bioenergy Generation Potential in Uganda. Environ. Res. Eng. Manag. 2017, 73, 45-53. [CrossRef]

54. Global Green Growth Institute. Kampala Municipal Solid Waste Value Chain Mapping; Technical Report; GGGI: Kampala, Uganda, 2018.

55. Arthur, R.; Brew-Hammond, A. Potential Biogas Production from Sewage Sludge: A Case Study of the Sewage Treatment Plant at Kwame Nkrumah University of Science and Technology, Ghana. Int. J. Energy Environ. 2010, 1, 1009-1015.

56. OAG. Management of Sewerage in Urban Areas by National Water and Sewerage Corporation; Technical Report; Office of the Auditor General: Kampala, Uganda, 2015.

57. Ocwieja, S.M. Life Cycle Thinking Assessment Applied to Three Biogas Projects in Central Uganda. Master's Thesis, Michigan Technical University, Houghton, MI, USA, 2010. 
58. Okure, M.; Tuhairwe, F.; Musinguzi, W.B. Technical and Economic Viability of Biogas-Based Electricity Generation for Distributed Renewable Energy Systems in Livestock Communities of Uganda. In Proceeding of the LeNSes Conference, Cape Town, South Africa, 28-30 September 2016.

59. Asante, K.P.; Afari-Asiedu, S.; Abdulai, M.A.; Dalaba, M.A.; Carrión, D.; Dickinson, K.L.; Abeka, A.N.; Sarpong, K.; Jack, D.W. Ghana's Rural Liquefied Petroleum Gas Program Scale up: A Case Study. Energy Sustain. Dev. 2018, 46, 94-102. [CrossRef]

60. MECS. Cooking with Electricity in Uganda: Barriers and Opportunities; Working Paper; Modern Energy Cooking Services Programme, University of Loughborough: Loughborough, UK, 2020.

61. Parawira, W. Biogas Technology in Sub-Saharan Africa: Status, Prospects and Constraints. Rev. Environ. Sci. Biotechnol. 2009, 8, 187-200. [CrossRef]

62. Owens, G. Best Practices Guide: Economic \& Financial Evaluation of Renewable Energy Projects; Technical Report; Energy and Environment Training Program Office of Energy, Environment and Technology Global Bureau, Center for Environment United States Agency for International Development: Washington, DC, USA, 2002.

63. GLPGP. Assessing Potential for BioLPG Production and Use within the Cooking Energy Sector in Africa; Technical Report; Global LPG Partnership: New York, NY, USA, 2020.

64. SKM Enviros. Analysis of Characteristics and Growth Assumptions Regarding ad Biogas Combustion for Heat, Electricity and Transport and Biomethane Production and Injection to the Grid (Reference No: 09/06/2010); Technical Report; Department of Energy and Climate Change: Washington, DC, USA, 2011.

65. Kemausuor, F.; Adaramola, M.S.; Morken, J. A Review of Commercial Biogas Systems and Lessons for Africa. Energies 2018, 11, 2984. [CrossRef] 